\title{
STATUS ANAK LUAR KAWIN DALAM HUKUM ADAT INDONESIA
}

\author{
Bernadeta Resti Nurhayati \\ Fakultas Hukum dan Komunikasi Universitas Katolik Soegijapranata \\ Semarang \\ Mahasiswa Program Doktor Ilmu Hukum Universitas Gadjah Mada \\ Yogyakarta \\ Email: bernadeta_resti@yahoo.com,resti@unika.ac.id
}

\begin{abstract}
ABSTRAK
Masyarakat membedakan perlakuan terhadap anak sah dan anak luar kawin. Demikian pula hukum membedakan anak menjadi anak sah dan anak luar kawin. Akibatnya status, kedudukan, serta hak anak luar kawin berbeda dengan anak-anak yang lahir dari perkawinan yang sah. Anak sah memiliki status keperdataan, kedudukan serta hak waris secara penuh. Namun tidak demikian halnya dengan anak luar kawin. Undang-Undang Perkawinan mengatur tentang anak luar kawin, namun tidak secara tuntas. Di sisi lain, hukum Adat Indonesia dengan keanekaragaman sistem kemasyarakatannya telah menempatkan anak luar kawin pada posisi yang cukup baik. Tulisan ini mendasarkan pada kajian kepustakaan, untuk meninjau bagaimanakah Hukum Adat memberikan penghormatan terhadap status anak luar kawin, khususnya sebagai sumber dalam pembentukan hukum positif untuk melindungi anak luar kawin.
\end{abstract}

Kata kunci : anak luar kawin, hukum adat.

\begin{abstract}
People discriminate the treatment between legitimate children and children born out of wedlock. Similarly, the law distinguishes children into legitimate children and children born out of wedlock. Consequently, the status, position, and rights of children born out of wedlock are different from children born in a legitimate marriage. Legitimate children havefull civil status, position and inheritance rights, but the children born out of wedlock do not. The Marriage Law regulates children born out of wedlock, but not completely. On the other hand, the Adat law of Indonesia with its diverse social system has put children born out of wedlock in a quite good position. This paper was based on the library study to review how adat law respects the status of children born out of wedlock, especially as a source in the formation of positive law to protect children born out of wedlock.
\end{abstract}

Keywords: children born out of wedlock, adat law

Pendahuluan

Masyarakat dan hukum membedakan anak menjadi "anak sah" dan "anak luar kawin". Entah sejak kapan pembedaan ini ada, tetapi pembedaan 
semacam ini telah lama dikenal di masyarakat. Masyarakat memberikan julukan anak luar kawin dengan beberapa istilah seperti: "anak haram jadah", "anak kampang", "anak sumbang", "anak kowar", "anak astra" dan sebagainya.Hukum pun sejak lama telah melakukan pembedaan ini. Kitab UndangUndang Hukum Perdata (KUHPerdata) Indonesia - berasal dari Burgerlijk Wetboek Belanda yang diberlakukan di Hindia Belanda berdasarkan asas konkordansi sejak tahun 1848 (Kansil, 2014) telah mengenal pembedaan itu. Pasal 250 KUHPerdata menyebutkan: "Tiaptiap anak yang dilahirkan atau ditumbuhkan sepanjang perkawinan, memperoleh si suami sebagai bapaknya". Ketentuan ini membedakan posisi anak menjadi "anak sah" dan "anak tidak sah" atau "anak luar kawin".

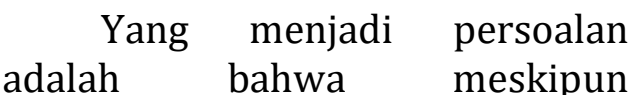
KUHPerdata yang berasal dari konsep Belanda itu masih berlaku di Indonesia pada saat ini, namun pada dasarnya KUHPerdata bukanlah hukum untuk orang Indonesia asli. C.S.T Kansil menyebutkan bahwa : hukum kodifikasi di Indonesia, terutama hukum perdata hanya berlaku bagi sebagian besar dari rakyat tertentu saja, sedangkan bagi golongan terbesar dari rakyat Indonesia berlaku susunan hukum perdata yang lain pula, yang pada umumnya tidak tertulis, yaitu hukum perdata adat (Hukum Adat) (Kansil, 2014).
Di bidang hukum perkawinan, saat ini berlaku Undang-Undang Nomor 1 Tahun 1974 tentang Perkawinan (UU Perkawinan). Pasal 43 UU Perkawinan mengatur tentang anak luar kawin. Namun pengaturan tersebut sangat sumir, karena mengatur soal anak luar kawin dalam satu pasal saja, yang menetapkan bahwa anak luar kawin hanya memiliki hubungan keperdataan dengan ibunya dan keluarga ibunya (ayat 1). Pasal 43 ayat (2) yang menjanjinkan untuk mengatur anak luar kawin dengan peraturan pemerintah, sampai saat ini tidak pernah dilaksanakan. Tahun 2012 Mahkamah Konstitusi mengeluarkan Putusan Nomor 46/PUU-VIII/20104 yang memberikan tafsir baru atas ketentuan Pasal 43 ayat (1) Undang-Undang Perkawinan sehingga pasal tersebut harus diartikan bahwa: Anak yang dilahirkan di luar perkawinan mempunyai hubungan perdata dengan ibunya dan keluarga ibunya serta dengan laki-laki sebagai ayahnya yang dapat dibuktikan berdasarkan ilmu pengetahuan dan teknologi dan/atau alat bukti lain menurut hukum mempunyai hubungan darah, termasuk hubungan perdata dengan keluarga ayahnya. Oleh karena itu pada dasarnya dibutuhkan suatu peraturan perundang-undangan yang secara khusus mengatur tentang anak luar kawin, termasuk lembaga-lembaga yang diperlukan demi melindungi anak luar kawin 
tersebut. Salah satu sumber yang dapat dijadikan sebagai sumber inspirasi pengaturan anak luar kawin adalah hukum adat, hal ini mengingat hukum adat merupakan hukum yang hidup di masyarakat. Tulisan ini tidak bermaksud menarik mundur dari pemikiran maju Mahkamah Konstitusi yang telah dituangkan dalam Putusan tersebut, namun hendak mencoba mengkaji tentang bagaimana hukum adat sesungguhnya menghormati kedudukan anak luar kawin dalam masyarakat, dan dapat digunakan sebagai dasar dalam pengaturan perihal anak luar kawin serta perlindungannya.

\section{Pembahasan}

\section{Pengertian Hukum Adat}

Istilah "Hukum Adat" merupakan terjemahan dari istilah bahasa Belanda "Adatrecht". Istilah ini pertama kali dipakai oleh Snouck Hurgronje. Istilah ini juga dikutip dan dipakai oleh van Vollenhoven sebagai istilah tehnis juridis (Muhammad, 1978). Bushar Muhammad (1978) menyebutkan bahwa kata "hukum adat" jarang digunakan. Masyarakat umum lebih sering menggunakan kata "adat" dibadingkan "hukum adat". Kata "adat" sebenarnya berasal dari bahasa Arab, yang berarti: "kebiasaan" (Taneko, 1987). Dalam bahasa-bahasa di Indonesia terdapat beberapa penyebutan/istilah, seperti: di daerah Gayo disebut : "Odot", di daerah Jawa Tengah dan Jawa Timur disebut "adat" atau "ngadat", di daerah Minangkabau disebut "lembaga (lambago)" atau "adat lembaga" kadang-kadang dipertentangkan antara adat dan lembaga karena "adat" adalah mengikat dan mempunyai akibat hukum, sedangkan "lembaga" tidak Mengikat dan tidak mempunyai akibat hukum. Di daerah Minahasa dan Maluku terdengar istilah "adat kebiasaan", di daerah Batak Karo istilah "adat" jarang sekali digunakan tetapi dipakai istilah "basa" atau "bicara" yang merupakan kebiasaan atau kesusilaan (Muhammad, op.cit).

Soekanto menyebutkan bahwa bagi ahli hukum yang mempunyai didikan Barat (westersche schooling), mempelajari hukum adat Indonesia ibarat masuk dalam dunia hukum baru yang sangat berbeda dengan apa yang biasa dijumpainya. Para ahli hukum didikan barat sudah biasa mempelajari hukum yang terdapat dalam peraturan-peraturan, dalam kodifikasi, dan mereka percaya atas didikannya bahwa hukum harus dibedakan dari adat istiadat, kesusilaan (moral), gaib, dan lain sebagainya (Soekanto, 1958).

Lebih lanjut disebutkan oleh Soekanto dikatakan bahwa dalam hukum di Indonesia terdapat sedikit hukum juris ("juristenrecht"); tetapi yang terbanyak adalah hukum rakyat ("volksrecht").10 Uraian Soekanto tersebut merupakan penegasan tentang kondisi hukum adat di Indonesia, bahwa di dalam masyarakat Indonesia yang beraneka rupa terdapat hukum yang hidup meskipun tidak pernah dikodifikasikan. 


\section{Sistem Hukum Adat Indonesia}

Masyarakat

Indonesia sungguhlah masyarakat yang plural. Indonesia memiliki 13.466 pulau yang terdaftar dan berkoordinat (Data Badan Informasi Geospasial). Dengan sedemikian banyak jumlah pulau maka amatlah logis bila terdapat beraneka adat dan budayanya. Ter Haar (1960) menyebutkan secara garis besar, masyarakatmasyarakat hukum di kalangan rakyat Indonesia dapat dibedakan menjadi: a. Masyarakat hukum (rechtsgemeenschappen); b. Masyarakat territorial; Yang dimaksudkan dengan masyarakat hukum atau rechtsgemeenschappen oleh Ter Haar adalah masyarakat genealogis. Pada masyarakat genealogis, mereka yang merasa menjadi anggota dari ikatan genealogis itu bersikap dan bertindak sebagai satu kesatuan. Iga Purwanti memberikan definisi genealogis sebagai suatu kesatuan

masyarakat yang teratur dimana para anggotanya terikat pada suatu garis keturunan yang sama dari suatu leluhur baik secara langsung karena hubungan darah (keturunan) maupun secara tidak langsung karena pertalian perkawinan atau pertalian adat. Pada intinya persekutuan hukum yang bersifat genealogis dilandaskan pada pertalian darah dan pertalian suatu keturunan (http://igapurwanti-

fh10/web.unair.ac.id). Mengenai masyarakat territorial adalah ikatan kemasyarakatan karena sama- sama tinggal di satu daerah/territorial yang sama. Dalam masyarakat territorial, ikatan genealogisya tidak berarti. Di Indonesia terdapat cukup banyak masyarakat-masyarakat yang sedemikian itu, dimana tidak begitu kuat ikatan genealogisnya, tetapi justru territorial yang lebih menonjol. Ter Haar menyebutkan desa-desa di Jawa, Sunda, Madura, Bali, gampong (meunasah) di Aceh, dusun-dusun di daerah Melayu, di Bangka dan Belitung, sebagian daripada gabungan-gabungan wilayah di Sumatra Selatan, gabungan-gabungan dusun dan wilayah-wilayah di Sulawesi Selatan,

negorij (negeri) di Minahasa dan di Ambon.14 Berbagai kelompok kekerabatan di dalam masyarakat menyebabkan perbedaan dalam hukumnya. Bila demikian tidak mengherankan bila Snouck Hurgronje yang memperkenalkan istilah "hukum adat" atau "adatrecht" pada akhir abad ke-19 menyebutkan terdapat sekurang-kurangnya lingkungan wilayah hukum adat di Indonesia. Perbedaan susunan kemasyarakatan berakibat berbeda pula berbagai sistem yang melingkupinya.

\section{Status Anak Luar Kawin dalam Sistem Hukum Adat Indonesia}

Anak merupakan generasi penerus keturunan. Oleh karena itu kedudukan anak di dalam keluarga -bagaimanapun bentuk kekerabatannya- menempati posisi yang penting untuk meneruskan garis keturunan. 
Posisi ini seringkali juga berkaitan dengan persoalan siapakah yang berhak untuk mewaris harta kekayaan pada umumnya maupun harta pusaka keluarga.

Mengenai anak luar kawin dalam hukum adat, Hilman Hadikusuma menyebutkan bahwa: "Pada dasarnya baik menurut hukum perundang- undangan maupun adat, untuk menentukan sah tidaknya si anak adalah dilihat pada kenyataan yuridis bukan kenyataan biologis." (Hadikusuma, 2003). Kenyataan yuridis yang dimaksudkan di sini adalah yuridis menurut hukum yang berlaku serta adat kebiasaan setempat. Dengan demikian, meskipun si ayah yuridis tidak sama dengan ayah biologisnya tidak menjadi persoalan secara hukum. Anak tersebut tetap anak sah, meskipun perkawinan kedua orangtuanya hanya bersifat "penutup malu". Di Jawa dikenal "nikah tambelan", atau di Bugis disebut "pattongkoq sirik" yang merupakan kawin darurat untuk melepaskan si perempuan dan keluarga dari rasa malu karena si perempuan hamil sebelum dilangsungkan.

Di lingkungan masyarakat adat Patrilinial yang berpegang teguh pada agama Islam, anak haram tidak berhak menjadi penerus keturunan bapaknya dan tidak berhak menjadi ahli waris dari bapaknya (Hadikusuma, 1987). Berdasarkan uraian tersebut dapat dipahami sebagai berikut: Anak haram dianggap bukan keturunan bapaknya, oleh karena itu si anak tidak berhak mewaris dari bapaknya. Secara $a$ contrario, bila anak haram tidak dianggap keturunan bapaknya, maka ia secara faktual adalah keturunan ibunya. Ini adalah fakta yang tidak dapat disangkal karena ibulah yang melahirkan si anak tersebut.

Menurut hukum adat Lampung (bersifat patrilineal), anak haram dijadikan anak masyarakat adat. Oleh karena itu si anak dikeluarkan dari kekerabatan adat bapaknya. Kerabat bapaknya harus membayar denda adat dan meminta maaf atas kesalahan anaknya (bapak biologis si anak luar kawin) pada majelis prowatin ( para batin = tua-tua adat $) \cdot 17$ Berdasarkan uraian tersebut nampak bahwa menurut adat kebiasaan di Lampung, anak haram dikeluarkan dari kekerabatan adat bapaknya, namun masyarakat adat tidak membuang keluar di anak haram begitu saja. Masyarakat adat masih melindungi si anak luar kawin dengan memberikan tempat, yakni sebagai "anak masyarakat adat". Perihal sanksi yang diterapkan oleh masyarakat adat, berupa pembayaran denda adat dan meminta maaf atas kesalahan anaknya kepada tua-tua adat. Hal ini merupakan bukti bahwa hukum adat mengenal sanksi, meskipun tidak membedakan secara tegas antara sanksi pidana ataukan sanksi perdata. Perhatikan pula bahwa sanksi dibebankan pada pihak keluarga laki-laki yang telah menyebabkan hamilnya si perempuan, dan bukan pada si perempuan. 
Menurut Hilman Hadikusuma, mungkin saja si anak haram itu masih dapat berhubungan dengan orangtua yang melahirkan dan diurus secara diam-diam oleh orangtuanya itu. Tetapi di dalam kedudukan adatnya anak tersebut tetap anak haram, ia tersingkir dari kerabatnya atau ia menyingkirkan diri sendiri karena merasa malu. Dalam waktu yang lama barulah dapat diterima kembali bergaul dalam masyarakat adat yang bersangkutan, atau ia pindah dan memenuhi susunan kerabat adat yang lain yang jauh dari kerabat asalnya dengan jalan adopsi (Lampung: mewari).

Di masyarakat adat beragama Kristen adakalanya anak yang lahir di luar perkawinan, hubungan anak dengan orangtuanya tidak berbeda dengan anak yang lahir di dalam perkawinan. Bahkan anak yang lahir di luar perkawinan dapat disahkan pula pada saat perkawinan orangtuanya. Di daerah Ambon ini disebut sebagai "Erken". Pada masa itu, di Ambon berlaku Ordonansi perkawinan orang-orang Kristen Jawa, Minahasa dan Amboina Staatsblad 1933 Nomor 74. Dapat diperkirakan bahwa Ordonansi perkawinan orang-orang Kristen ini kiranya terpengaruh oleh konsep kelembagaan dan pengaturan anak luar kawin sebagaimana diatur dalam Kitab Undang-Undang Hukum Perdata.

Bagaimana dengan masyarakat ber-kekerabatan Matrilineal? Anak tidak sah di
Minangkabau, seperti juga di daerah lain yang kuat agama Islamnya, adalah anak haram, anak hasil perbuatan "sumbang salah". Sebagai akibat perbuatan zina tersebut maka ayah dan ibu biologis si anak, beserta anak haramnya menurut hukum adat dijatuhi hukuman buang. (Minang: buang sirih, buang biduk, buang tingkarang, buang daki) (Hadikusuma, 1987). Akibat dijatuhi hukuman buang itu, maka kewargaan adat seseorang hilang. Meskipun saat ini ada kecenderungan bahwa masyarakat adat cenderung membiarkan saja kejadian itu, hanya saja pada umumnya kehidupan ibu dan anak yang sumbang salah itu untuk sementara waktu tersingkir dari hubungan kekerabatannya.

Pada masyarakat parental, antara lain disebutkan bahwa: "Ketergantungan anak pada ibu saja akan lebih nampak pada ibu yang dalam perkawinan dengan bapaknya berkedudukan seperti isteri selir atau sebagai isteri yang tidak kawin syah, yang disebut "isteri piaraan". Bila kita perhatikan maka sistem ini sama dengan sistem yang digunakan dalam konsep hubungan antara anak luar kawin dengan ibu yang melahirkannya dan keluarga ibunya, sebagaimana diatur dalam Pasal 43 ayat (1) Undang-Undang Nomor 1 Tahun 1974 tentang Perkawinan.

Di Minahasa anak di dalam atau di luar perkawinan sama saja sebagai anak yang sah. Untuk memperkuat pengakuan bapak terhadap anak yang lahir dari 
ibunya di luar perkawinan, maka bapaknya memberi "lilikur" (hadiah adat, biasanya berupa tanah) bagi perempuan yang tidak dinikahinya jika bapak dan si-ibu hidup terpisah. Bila ada pembayaran "lilikur", maka ada kemungkinan si anak luar kawin ada kemungkinan mendapatkan bagian harta warisan bukan saja dari ibunya tetapi juga dari bapaknya. Demikian juga di Bali, anak yang lahir dari percampuran pria dan wanita sebelum perkawinan dilaksanakan adalah sah. Di kalangan orang Jawa, pemberian warisan kepada anak haram (Jawa: anak kowar) dimungkinkan karena asas peri kemanusiaan (Jawa: parimirma, welas asih). Di beberapa daerah di Indonesia, misalnya di Mentawai dan Timor, anak itu dianggap seperti anak yang mempunyai ibu yang menikah (Mustari Pide, 2014,). Ter Haar pun menyebutkan bahwa : Anak yang lahir di luar perkawinan (penulis: anak luar kawin) dalam beberapa lingkungan hukum ber-ibu perempuan tak berkawin yang melahirkannya, sebagaimana seorang anak terlahir dalam perkawinan ber-ibu si-perempuan yang melahirkan dia (di Minahasa, Ambon, Timor, Mentawai) (Ter Haar, op.cit).

Pandangan berdasarkan adat kebiasaan di masyarakat ini merupakan penghormatan terhadap perempuan dan anak yang dilahirkannya, meskipun anak tersebut adalah anak luar kawin. Anak luar kawin tetaplah diakui sebagai entitas, sebagai subjek hukum yang tidak beda dengan anak sah. Terlebih bila anak tersebut telah diakui dan disahkan dengan perkawinan26 antara ayah dan ibu biologisnya. Anak tetaplah milik ibunya, meskipun dalam beberapa kasus kadang-kadang si ibu tidak mau memelihara anak yang dilahirkannya karena tidak berasal dari hubungan yang sah, tetap bahwa secara fakta anak tersebut adalah anak dari perempuan tersebut.

Berdasarkan uraian tersebut di atas, nampak bahwa masyarakat Indonesia telah lama mengenal namun juga membedakan anak menjadi anak sah dan anak luar kawin. Di beberapa tempat anak luar kawin dianggap bukan merupakan keturunan bapak biologisnya. Sebagai konsekuensinya, maka anak luar kawin juga tidak memiliki hubungan keperdataan dengan bapak biologisnya serta bukan merupakan ahli waris dari bapak biologisnya.

Di beberapa territorial, anak luar kawin tetap memiliki hubungan dengan bapak biologisnya dan mendapatkan pemeliharaan dari bapak biologisnya tersebut. Hal ini sejalan dengan Putusan Mahkamah Konstitusi Nomor 46/PUUVIII/2010 yang membuka peluang bagi bapak biologis untuk memiliki hubungan keperdataan dengan anak luar kawinnya. Ini dengan catatan bahwa hubungan tersebut dapat dibuktikan baik secara ilmu pengetahuan atau bukti-bukti lain yang memungkinkan, bahwa anak luar 
kawin tersebut adalah anak biologis si bapak.

$$
\text { Selain itu di masyarakat }
$$
Minahasa dan Ambon, dimungkinkan bagi ayah biologis yang akhirnya menikah dengan ibu si anak luar kawin, untuk melakukan pengakuan dan pengesahan anak luar kawin. Dengan demikian dapat dikatakan bahwa semestinya harus dibuka peluang dilakukannya "pengakuan anak" serta "pengesahan anak" dalam peraturan perundangan dengan mendasarkan pada hukum kebiasaan yang berlaku dalam masyarakat. Bandingkan hal ini dengan praktek yang berlaku saat ini, bahwa pengakuan anak serta pengesahan anak luar kawin didasarkan pada ketentuan KUHPerdata yang pada dasarnya adalah hukum yang ditujukan bagi keturunan golongan Eropa dan keturunan golongan Timur Asing. Ketentuan tentang pengakuan anak serta pengesahan anak luar kawin saat inipun juga dibatasi oleh Undang-Undang Nomor 24 Tahun 2013 tentang Perubahan Undang-Undang Nomor 23 Tahun 2006 tentang Administrasi dan Kependudukan. UU Nomor 24 Tahun 2013 ini dalam Pasal 1 angka 10 dan 11 merevisi ketentuan Pasal 49 dan 50 UU Nomor 23 Tahun 2006, yang pada intinya pengakuan anak serta pengesahan anak dibatasi hanya boleh dilakukan oleh mereka (pasangan suami isteri yang sebelumnya telah menikah secara hukum agama). Ketentuan ini menghilangkan/membatasi hak untuk diakui atau disahkan, dari anak luar kawin yang bapak dan ibu biologisnya belum menikah secara agama.

Dengan melihat berbagai pengaturan yang ada, baik dalam KUHPerdata, UndangUndang Perkawinan, UndangUndang Nomor 23 Tahun 2006 tentang Administrasi dan Kependudukan, Undang-Undang Nomor 24 Tahun 2013 tentang Perubahan Undang-Undang Nomor 23 Tahun 2006 tentang Administrasi dan Kependudukan, dan tentu saja hukum Islam serta hukum adat sebagai hukum yang hidup di masyarakat, seharusnya dilakukan harmonisasi pengaturan yang ada bagi anak luar kawin. Harmonisasi ini perlu dituangkan dalam satu undang-undang yang secara khusus mengatur hak serta kelembagaan yang dapat disediakan oleh pemerintah untuk memberikan perlindungan hukum bagi anak luar kawin. Hal ini sebagai bentuk komitmen Pemerintah dan masyarakat untuk secara bersama-sama memberikan perlindungan terhadap hak-hak keperdataan pada anak luar kawin.

\section{Penutup}

Berdasarkan uraian tersebut di atas dapat disimpukan sebagai berikut:

a) Hukum adat memberikan tempat yang khusus bagi anak luar kawin,yang secara umum dapat dibedakan menjadi dua : (1) anak luar kawin tidak memiliki hubungan darah dan hubungan keperdataan dengan ayah biologisnya. Dengan demikian anak luar kawin bukan 
keturunan dan bukan ahli waris ayahnya. Perkecualian bila bapak biologis mengakui anak tersebut dengan melakukan pengakuan "Iilikur" (di Menado), atau bapak dan ibu biologis menikah satu sama lain (di Ambon). Dengan "lilikur" anak luar kawin ikut mewaris dari bapak biologisnya. Di Jawa anak luar kawin bisa mewaris karena parimirma/welas asih. (2) anak luar kawin dalam beberapa lingkungan hukum ber-ibu perempuan tak berkawin yang melahirkannya, sebagaimana seorang anak terlahir dalam perkawinan ber-ibu si-perempuan yang melahirkan dia (di Minahasa, Ambon, Timor, Mentawai). b) Ada upaya dari masyarakat untuk mencegah terjadinya/lahirnya anak luar kawin, yakni berupa sanksi/denda adat dan pelaksanaan lembaga yang dikenal dalam hukum adat seperti: kawin darurat, kawin tambelan, pattongkoq siriq. c) Perlu dilakukan harmonisasi terhadap peraturan perundangan yang ada dengan mempertimbangkan norma-norma dalam hukum adat dan hukum Islam sebagai hukum agama dari merupakan agama mayoritas masyarakat Indonesia.

\section{Daftar pustaka}

C.S.T. Kansil dan Christine S.T. Kansil, Sejarah Hukum di Indonesia, Jakarta: PT. Suara Harapan Bangsa.

Hilman Hadikusuma, 1978, Sejarah Hukum Adat Indonesia, Bandung: Penerbit Alumni.
1987, Hukum Kekerabatan Adat, Cetakan Pertama, Jakarta: CV Fajar Agung.

----------, 1989, Hukum Waris Adat, Bandung: Alumni.

-------, (tt), Pengantar Ilmu Hukum Adat Indonesia, Bandung: Mandar

Maju.

$\begin{array}{ll}\text { 2003, } & \text { Hukum } \\ \text { Perkawinan Adat dengan } \\ \text { Adat Istiadat dan }\end{array}$

Upacara Adatnya, Bandung: Citra Aditya Bakti.

Imam Sudiyat, 1981, Hukum Adat Sketsa Asas, Yogyakarta: Liberty. Soekanto, 1958, Menindjau Hukum Adat Indonesia, Djakarta: Penerbit

Soeroengan.

Suriyaman Mustari Pide, 2014, Hukum Adat Dahulu, Kini dan Akan Datang,

Edisi Pertama, Jakarta: Prenadamedia Group.

Ter Haar, B.,Bzn, 1960, Asas-asas dan Susunan Hukum Adat, Jakarta: Pradnja Paramita d/h. J.B. Wolters

Yaswirman, 2013, Hukum Keluarga, Karakteristik dan Prospek Doktrin Islam dan Adat dalam Masyarakat Matrilinneal Minangkabau, Cetakan kedua, Jakarta: PT. Rajagrafindo Persada.

http://www.bakosurtanal.go.id, Data Badan Informasi Geospasial, diakses

17 Februari 2016.

http://igapurwantifh10/web.unair.ac.id, diakses 22 februari 2016. 